\title{
OTRI5. DESENVOLVIMENTO DA CULTURA PRIMÁRIA DE HEPATÓCITOS DE EMBRIÃO DE Gallus gallus domesticus PARA DETECÇÃO DE AGENTES ADVENTÍ́CIOS EM VACINAS VIRAIS.
}

Mariana Nogueira da Silva Teixeira ${ }^{1}$; Jaline Coutinho Silvério Antunes ${ }^{1}$; Pedro Augusto Alves ${ }^{1}$; Marcelo Alex de Carvalho²; Renata Soares Dias de Souza ${ }^{3}$; Natália Pedra Gonçalves ${ }^{1}$; Daniel da Silva Guedes Jr. ${ }^{1}$.

${ }^{1}$ Bio-Manguinhos / Fiocruz;

${ }^{2}$ Instituto Federal de Educação, Ciência e Tecnologia do Rio de Janeiro;

${ }^{3}$ Instituto Oswaldo Cruz.

INTRODUÇÃo A utilização de cultura de células para a produção de imunobiológicos apresenta possíveis riscos à biossegurança do produto, dentre eles a presença de vírus ou agentes oriundos dos insumos utilizados no preparo e manutenção da cultura, modelo animal, ambiente, equipamentos, manipuladores, dentre outros. Classificase como agente adventício qualquer microrganismo ou vírus contaminante de cultura de células ou matérias-primas que tenham sido introduzidos não intencionalmente durante o processo produtivo. As diretrizes regulamentares que norteiam as análises mandatórias ao Controle de Qualidade incluem a realização de testes de detecção através de substratos celulares, que oferece vantagens quando comparados aos métodos imunológicos e biomoleculares, contudo sem excluí-los. A implementação da cultura primária de hepatócitos consiste em uma plataforma que permite a multiplicação destes agentes, aumentando assim as chances de detecção por efeito citopático e hemadsorção. A literatura científica descreve casos de contaminação por agentes adventícios, enfatizando a relevância da compreensão do processo produtivo para identificar possíveis fontes de contaminação, bem como a importância de um controle de qualidade extensivo para resguardar a eficácia e pureza do produto antes de ser lançado no mercado. Ademais, o desenvolvimento desta cultura em Bio-Manguinhos contribui para o cumprimento de uma das etapas da transferência de tecnologia para nacionalização da vacina contra Sarampo, Caxumba e Rubéola, com a implementação desta análise in house.

OBJETIVO Este trabalho teve como objetivo padronizar a metodologia para a cultura primária de hepatócitos de embriões SPF de Gallus gallus domesticus a ser implementada no Controle de Qualidade de Bio-Manguinhos como mais uma 
plataforma de pesquisa de agentes adventícios, garantindo assim a segurança viral do produto final.

METODOLOGIA Para a obtenção do fígado, foram utilizados 4 ovos SPF embrionados de 16 a 18 dias. Os embriões foram eutanasiados por decapitação e em seguida a cavidade celomática foi aberta para excisão do fígado e posterior fragmentação. Procedeu-se com a digestão enzimática com colagenase a 0,05\% e separação celular por sucessivas centrifugações e posterior decantação. A suspensão celular obtida foi quantificada e ajustada para $1,5 \times 10^{6}$ células $/ \mathrm{mL}$, e em seguida inoculada em placa de 6 poços revestida com colágeno. A cultura primária foi incubada em estufa a $37^{\circ} \mathrm{C}$ e monitorada diariamente para verificar a formação da monocamada.

RESULTADOS Imediatamente após a inoculação em placa, foi observada presença predominante de células arredondadas, com vesículas de lipídeo, correspondentes aos hepatócitos. Estas células espraiaram no substrato após 4h de adesão, formando ilhotas de hepatócitos após $48 \mathrm{~h}$ com presença de alguns fibroblastos. Em aproximadamente 4 dias, foi possível obter uma monocamada confluente de hepatócitos poligonais com vesículas lipídicas nos citoplasma e núcleo contendo de 1 a 2 nucléolos.

CONCLUSÃO A metodologia para o isolamento e cultura primária de hepatócitos foi padronizada, com tempo de sobrevivência da cultura em até 10 dias.

PALAVRAS-CHAVE agentes adventícios, controle de qualidade, cultura primária, hepatócitos, tríplice viral. 